\title{
Westinghouse GOCO \\ Conduct of Casualty
} Drills

Prepared for the U.S. Department of Energy Assistant Secretary for Environmental Management

\section{(2) Westinghouse}

Management and Operations Contractor for the

U.S. Department of Energy under Contract.DE-AC06-87RL10930 


\section{IEAM DISCLAME}

This report wes prepared as en eccount of work oponsored by in eponoy of the United Stetes Governiment. Nather the United States Government nor emv ageney thereof, nor enY of their omployees, nor eny of their contrectors abcontrectors or their employees, makes any warranty, express or appliad, or aseumes any legal fiebility or responsibitity for tho accuracy, completenese of eny thind party s ues of the rosthe of such use of any information, apparatus, product, or procese disclosed, or represents that its uee would not infinges privetely owned rights. Reference horein to eny spocific commercial product, process, or service by tredeneme, 1 ) tredemark, manufacturer, or otherwies, does not nooeseonify constitute or imply its endorsement, rocommendation of fevoring by the United States Government or any epency thereof or its contractors or abcontrectors the vewa and opinions of authors expresesd horein do not nocesestly dtete or refloct those of the United States Govornmont or any egency thereof.

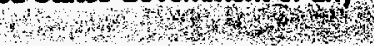

$y^{3} x^{2}$

This report has been reproduced from the best ovallablo copy. Aveilable in peper copy and microfiche.

Availablo to the U.S. Departmont of Enorgy and ise contrectors from U.S. Department of Enorgy Office of Scientific and Tochnica Information (OST)

P.0. Box 62

Oak Ridge, TN 37831

(615) $576-8401$

Printed in the United Stotes of Amaries

DISCLM-3.CHP (1-91) 


\title{
Westinghouse GOCO Conduct of Casualty Drills
}

\author{
C. P. Ames
}

Date Published

February 1996

Prepared for the U.S. Department of Energy Assistant Secretary for Environmental Management

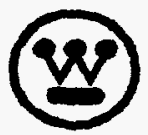

Management and Operations Contractor for the

U.S. Department of Energy under Contract DE-AC06-87RL 10930

Approved for public release; distribution is unlimited 


\section{DISCLADMER}

Portions of this document may be illegible in electronic image products. Images are produced from the best available original document. 


\section{RELEASE AUTHORIZATION}

\section{Document Number: WHC-SP-1178}

Document Title: Westinghouse GOCO Conduct of Casualty Dri11s

Release Date: $\quad 2 / 15 / 96$

This document was reviewed following the procedures described in WHC-CM-3-4 and is:

\section{APPROVED FOR PUBLIC RELEASE}

WHC Information Release Administration Specialist:

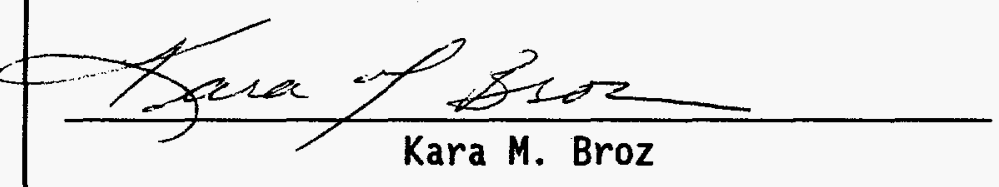


WESTINGHOUSE GOCO

CONDUCT OF CASUALTY DRILLS
Manual

Section Table of Contents, Rev 0

Page

Effective Date
WHC-SP-1178

$i$ of $i j$

February 15, 1996

TABLE OF CONTENTS

I. INTRODUCTION

A. Purpose

B. Objective and Benefits of a Casualty Drill Program

C. Essential Elements of a Casualty Dril1 Program

1. A Documented Casualty Drill Program

2. Trained Dril1 Team(s)

3. Drill Scenarios

II. A DOCUMENTED CASUALTY DRILL PROGRAM
A. Scenario Development
B. Pre-Drill Brief
C. Drill Performance
D. Critique
E. Records

III. TRAINED DRILL TEAM(S)
A. Dri11 Coordinator
B. Drill Controller

IV. DRILL SCENARIOS
A. Initial Conditions
B. Precautions and Limitations
C. Drill Initiation
D. Expected Response
E. Termination and Restoration 


\section{TABLE OF CONTENTS (CONTINUED)}

V. ALTERNATE FACILITY OPERATOR TRAINING

A. Theory-to-Practice Exercise

B. Table-Top Discussion

C. Monitored Evolution

VI. ATTACHMENTS
A. Definitions
B. Examples of Standard Simulations
C. Dri1l Evaluation/Critique
D. Blank Drill Scenario
E. Completed Drill Scenario
F. List of Suggested Casualty Dri11s
G. References and Resources

VII. REFERENCES AND RESOURCES 


\section{CHAPTER I: INTRODUCTION}

\section{A. PURPOSE}

The purpose of this document is to provide Westinghouse Government Owned Contractor Operated (GOCO) Facilities with information that can be used to implement or improve drill programs. The elements of this guide are highly recommended for use when implementing a new drill program or when assessing an existing program.

Casualty drills focus on response to abnormal conditions presenting a hazard to personnel, the environment, or equipment. Casualty drilis are distinct from Emergency Response Exercises in which the training emphasis is on site, field office, and Emergency Management Team interaction.

The following DOE documents require team training and conducting drills in nuclear facilities and, in addition, should be used as guidance in non-nuclear facilities:

DOE 5480.19: The guidelines in Chapter 1 of Attachment I state that management is responsible for ensuring personnel are well trained.

DOE 5480.20: Chapter 1, paragraphs 7 a. and $d$. of continuing training specifically state that team training and drills should be components of a training program.

Casualty drills should be an integral part of the qualification and training program at every DOE facility. Proper response to casualty conditions is vital to ensuring personnel safety and protecting the environment and equipment. Personnel must be able to take the immediate actions necessary to safely mitigate the consequences of an unexpected or abnormal and potentially dangerous condition.

\section{B. OBJECTIVE AND BENEFITS OF A CASUALTY DRILL PROGRAM}

The primary objective of a casualty drill program is to train operators. A second objective is to provide a performance based assessment of the training program.

Casualty drills are an integral component for safe and efficient facility operations. To ensure success, casualty drill participation should be integrated into initial operator qualification and continuing training.

The following are benefits of a successful casualty drill program:

- Casualty Control

- Equipment Checkout

- Procedural Verification 
- Communication Improvement

- Teamwork Development

- Demonstration of training effectiveness to oversight organizations

- Disciplined Operations

C.

\section{ESSENTIAL ELEMENTS OF A CASUALTY DRILL PROGRAM}

The complexity and capabilities of a casualty drill program will vary with facility size and risk. A high risk, high complexity facility will need to establish a program that reflects the risk and complexity of that facility. A low risk, low complexity facility will need to establish a program appropriate to it. For example the casualty drill program for a reactor facility may involve 20 people, whereas the casualty drill program of a site support facility may involve just one individual.

Regardless of the size, complexity, and risk of a facility, an effective casualty drill program must include the following essential elements:

- A Documented Casualty Drill Program

- Trained Drill Team(s)

- Drill Scenarios

The remainder of this guidance document will describe each of these essential elements in detail and provide suggested good practices associated with each element. Facility management must determine the appropriate level of effort and resources to implement those good practices which will support the casualty drill program commensurate with the risk and complexity of the facility. 


\section{CHAPTER II: A DOCUMENTED CASUALTY DRILL PROGRAM}

A documented casualty drill program defines the mechanics for conducting drills. The mechanics include scenario development, training of drill team members (discussed in detail in Chapter III), pre-drill brief, drill performance, critique, and records.

\section{A. SCENARIO DEVELOPMENT}

All casualty drills should be conducted in accordance with an approved written scenario. The method of preparation and approval authority must be del ineated in the program. Any individual may prepare a drill scenario. Examples of possible drill scenarios are included in Attachment F. Qualified individuals should validate the proposed scenario to determine its credibility, technical accuracy, and safety implications. As a minimum, the Facility Manager (see definition in Attachment A) is required to approve drill scenarios and any subsequent modifications to the scenario.

\section{B. PRE-DRILL BRIEF}

Drill Team members should attend a pre-drill brief. Review of the dri11 scenario is required. Particular attention should be given to recent changes in plant status, on-going maintenance, or out-of-service equipment which could affect safety margins.

Drill Controllers should be assigned where disclosures must be made, improper actions could cause problems, or oversight is required. A dedicated communications method for the Drill Team could be specified to allow coordinated and realistic simulations.

A clear method for directing that the drill be stopped and normal or stable conditions restored should be specified. All drill participants must be trained to recognize and respond to that signal.

Pre-drill discussions should include the "what ifs?", possible problems, and unplanned events. Other areas of discussion could include the following:

- How can this particular drill or the way it's planned go wrong?

- What contingency plans are available?

- What went wrong the last time this drill was run, and how can it be avoided?

\section{c. DRILL PERFORMANCE}

The documented casualty drill program should state how drills are performed to include drill initiation, drill simulation, drill termination, and facility restoration. 
Program guidance on drill initiation should include a check that drill team members are on station, initial conditions are verified, and that approval to conduct a drill has been obtained.

The dril1 program guidance should provide a list of recognized simulations such as 7 isted in Attachment B. Drill simulations should provide the necessary information (alarms, indications, gage readings, reports, etc.) for drill participants to respond appropriately.

Written guidance should be provided to properly terminate a casualty drill. In addition, guidance should be given to properly restore the facility to a stable condition. For instance a drill could be terminated that will "conveniently" result in a component shutdown for maintenance.

\section{CRITIQUE}

Program guidance should include the requirements for timely dri11 evaluation and identification of deficiencies.

A drill critique is not a chronology of events. It is an analysis of what went wrong and what went right. A critique should be held in a timely manner (immediately following the dri11 or dri11 set is preferred) and chaired by the Drill Coordinator. Comments should be solicited from the participants. Notes should be kept so that the critique can be referred to the next time that particular drill is run. Lessons learned must be promulgated to all appropriate facility personnel to ensure the maximum training value is gained.

Deficiencies in training, equipment, and procedures identified in the critique need to be documented and corrected. An example form is provided in Attachment $C$.

\section{E. RECORDS}

The program guidance should include maintenance of scenarios, schedules, completion of drills, critique reports, and post-drill corrective action items. 


\section{CHAPTER III: TRAINED DRILL TEAM(S)}

The Drill Team consists of the Drill Coordinator and Drill Controllers. The functions of the drill team are to provide initiation, ensure safety, and to evaluate. Prior to conducting casualty drills, a drill team should be assembled and trained on their respective positions. The Drill Team shall be qualified to the extent necessary to ensure facility safety.

\section{A. DRILL COORDINATOR}

The Drill Coordinator should be designated by the Facility Manager. The Dri11 Coordinator is responsible for the briefing, conduct, and critique of the drill. The Drill Coordinator may be the Line Manager or his designate (i.e., a supervisor or a senior crew member). Specifically, the Drill Coordinator is responsible for the following:

- Ensure necessary approvals of the scenario and initiation authorizations are obtained prior to conducting the dri11.

- Assign Drill Controllers to conduct the drill as required by the written drill scenario.

- Coordinate and conduct a pre-drill briefing for the Drill Controllers to ensure complete understanding of the scenario, limits, abort conditions, and any required actions that may be necessary to maintain safety.

- Ensure completion of any pre-dritl notifications.

- Verify the status of the plant, initial conditions, and readiness of the Line Management to begin the drill.

- Coordinate and conduct the dri17.

- Abort the dri11 any time conditions warrant.

- Terminate at the completion of the drill.

- Ensure the post-dri11 restoration and removal of simulations.

- Ensure that any post-drill notifications have been made.

- Conduct a critique with all personnel involved in the drill.

- Draft and submit a written critique to the appropriate managers for review.

\section{B. DRILL CONTROLLER}

The Drill Controller(s) have the responsibilities of initiator, safety observer, and/or evaluator. The responsibilities listed below may be performed by one or more people: 


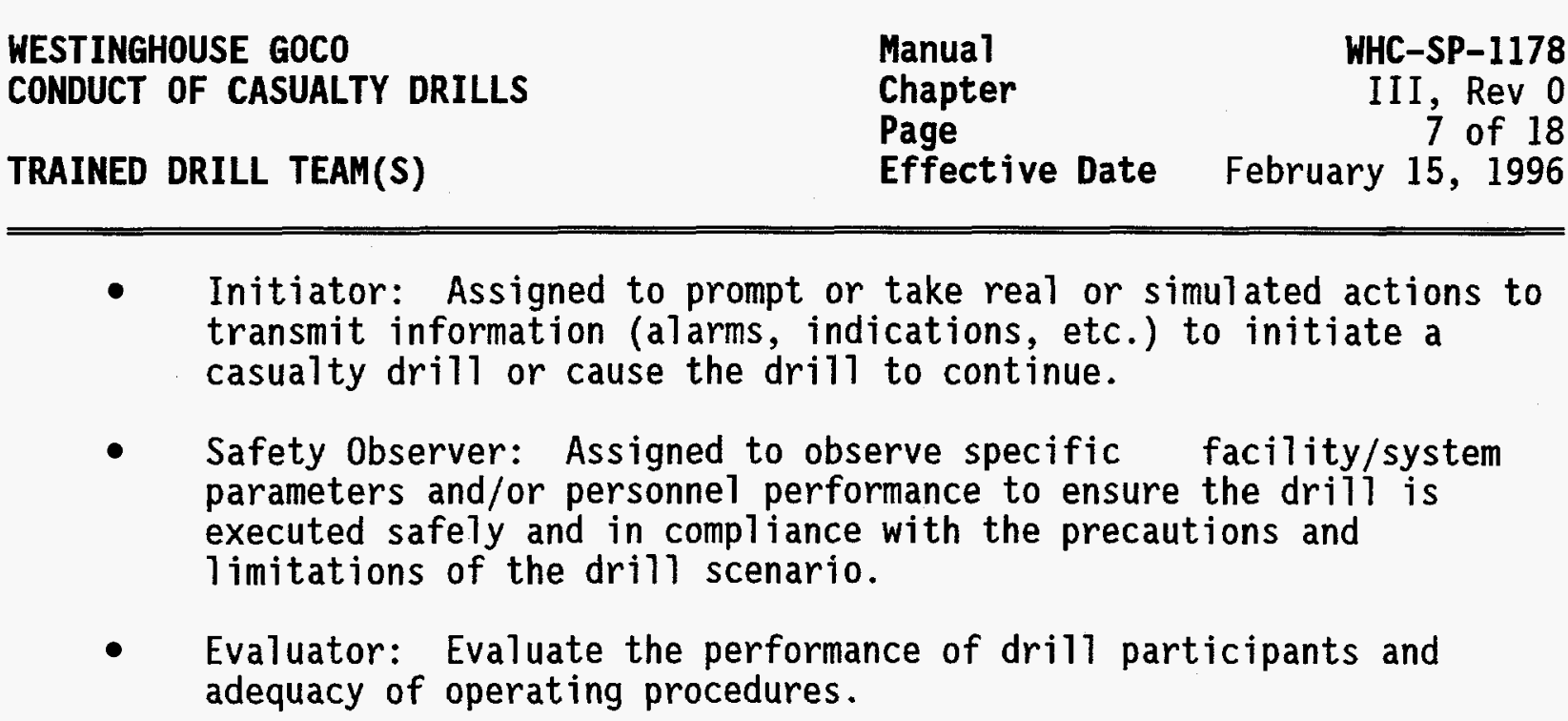




\section{CHAPTER IV: DRILL SCENARIOS}

A collection of drill scenarios for each facility should be created and approved by the Facility Manager. These casualty drills will exercise operators in the use of casualty procedures considered essential to basic operator training for a given facility. A scenario is needed for each of the casualty conditions requiring operator response. An example of a blank and a completed drill scenario are provided as Attachment $D$ and $E$, respectively.

Simple drills will often accomplish training objectives more effectively than their more complicated counterparts. For example, if the objective is to evaluate operator response to a fire, simulate a paper fire in a trash can. Once operator proficiency is gained for this casualty, consider increasing drill complexity. An example would be a fire in a trash can which results in an injured person. Another way of increasing complexity is to simulate a fire of a Targer magnitude.

This progression could be applied to numerous types of casualties including equipment anomalies, radiological control incidents, loss of electrical power, and process specific casualties. Using a standard scenario, drills can be developed that cover a wide spectrum of complexity. A list of suggested casualty drills is given in Attachment $F$.

Initial conditions, precautions and limitations, drill initiation, expected response, and termination and restoration are components that should be included in all casualty drill scenarios.

\section{A. INITIAL CONDITIONS}

The plant and equipment configuration for initiating the casualty drill should be specified. These initial conditions should be specific, but not so prescriptive as to reduce the flexibility of the drill. Affected plant personnel should also be identified.

Provisions must be made for pre-drill notifications and any other specific configurations or simulations. For example, advance notifications to the Fire Department, Security, Emergency Control Center, etc., must be identified.

\section{B. PRECAUTIONS AND LIMITATIONS}

Precautions and limitations should address abort limits, operational limits, safety limits, drill team duties, and identify applicable procedures, alarm response guides, etc., to be used during the dri11.

Appropriate limiting conditions which will cause the team to stop the drill should be specified. These abort limits must be-based on risk of personnel injury, equipment damage, or environmental damage. They may al so specify the criteria by which the performance is determined to be unsatisfactory.

\section{DRILL INITIATION}


The exact actions for the drill team to initiate the drill should be identified. There must be a set of disclosures keyed to each of the drill team members. These disclosures must al so specify the time and location in which the disclosure is to be made. This should guarantee a logical, consistent, and comprehensive presentation of the scenario. The intent is to provide indications which are realistic enough that operators can, without prompting from the drill team, analyze the hypothesized situation, reach correct conclusions, and take the prescribed action as if real plant parameters had existed. The key to success is using disclosures which provide appropriately realistic symptoms while also providing qualified operators with consistent, logical, comprehensive clues.

\section{EXPECTED RESPONSE}

The expected response of the $\mathrm{pl}$ ant and operators to the drill simulation should be described. The applicable procedures to be used by the operators should also be identified.

\section{E. TERMINATION AND RESTORATION}

The point at which the objectives of the drill have been met should be specified so that the drill can be formally terminated. The final facility condition should be identified and should include the removal of drill simulations. Any post-drill notifications required should be identified. 


\section{CHAPTER V: ALTERNATE FACILITY OPERATOR TRAINING}

In addition to casualty drills, three alternate methods of facility operator training include theory-to-practice exercises, table-top discussions, and monitored evolutions. For each of these alternate methods of facility operator training, the essential elements of a casualty drill program that were previously described should be included, as applicable.

\section{A. THEORY-TO-PRACTICE}

One method of training personnel or testing knowledge of facility system interrelationships is a theory-to-practice exercise. A theory-topractice exercise is conducted by selecting a variable system parameter, theorizing the response of that parameter to a given action, and then performing that action to see if the parameter varies as predicted.

\section{B. TABLE-TOP DISCUSSION}

A training program can also be highly effective by substituting table-top discussions in place of casualty drills. Table-top discussions involve the talk-through of an evolution or casualty drill without any actual facility manipulation. A facilitator selects an evolution or casualty dri11 scenario, and the table-top participants discuss various aspects of the scenario such as expected operator actions and prior lessons learned.

\section{MONITORED EVOLUTION}

A monitored evolution consists of a planned activity performed by a qualified operator. A controller observes the evolution to determine operator proficiency, procedure compliance, and procedure adequacy. 


\section{ATTACHMENT A}

\section{DEFINITIONS}

Casualty: Abnormal condition presenting a hazard to personnel, the environment, or equipment.

Disclosures: $\quad$ Real or simulated actions taken to initiate or provide realistic drill scenario conditions.

Dri11: A supervised, hands-on exercise intended to test, develop, and/or maintain proficiency of operators and supervisors to respond to a casualty condition.

Drillmanship:

Drill Controller:

Drill Coordinator:

Dril1 Critique:

Drill Scenario:

Drill Team:

Evolution:

Facility Manager:

Line Manager:
Concepts of dri11 conduct and expected p 7 ayer performance. This is also known as "playing the game."

A qualified or certified individual briefed on the drill to be conducted and assigned to prompt or take real or simulated operator actions.

Person who is responsible for the briefing, conduct and critique of a drill.

An evaluation of the casualty dri11.

A document describing a casualty condition which includes a description of the casualty, approvals, initial and final facility conditions, drill simulations, intervention points, and other information which can be useful when conducting the dri11.

Personnel who will be responsible for drill initiation, drill simulation, plant safety and/or dri11 critique.

A facility event or operation that follows prescribed procedures without the imposition of simulations.

The cognizant manager having direct line management responsibility, including authority for direct operation of the facility, and having intimate knowledge of the details of the day-to-day operations of the facility.

The senior individual designated by the position description as responsible for all aspects of operation of the facility assigned and to whom all operations personnel report during the assigned shift. 
Manual

Attachment

Page

Effective Date
WHC-SP-1178

$B, \operatorname{Rev} 0$

12 of 18

STANDARD SIMULATIONS

\section{EXAMPLES OF STANDARD SIMULATIONS}

Controller waving grey plastic bag - light smoke

Controller waving black plastic bag - heavy smoke

Controller waving red plastic bag - fire

Controller waving white bag - fire is out

Confetti - explosion

Blue cloth on floor - acid spill

Yellow cloth on floor - radioactive spill

Orange cloth on floor - caustic spill

Electronic buzzer - alarm

Crumpled aluminum foil taped to a pipe - ruptured pipe

Circuit breaker position indicator signs:

Breaker open

Breaker closed

Breaker tripped

Valve position indicator signs:

Valve open

Valve shut

Valve throttled 
WESTINGHOUSE GOCO

CONDUCT OF CASUALTY DRILLS

DRILL EVALUATION/CRITIQUE
Manual

Attachment

Page

Effective Date
WHC-SP-1178

$C, \operatorname{Rev} 0$

13 of 18

February 15, 1996

\section{ATTACHMENT $C$}

\section{DRILL EVALUATION/CRITIQUE}

DRILL NUMBER:

CREW:

DRILL TITLE:

DATE:

PROCEDURAL DISCREPANCIES:

COMMUNICATIONS DEFICIENCIES:

MATERIAL DISCREPANCIES DISCOVERED BY OR DURING THE DRILL:

DRILL CONTROLLER, DRILL INITIATION, SIMULATION DEFICIENCIES:

OPERATOR DEBRIEF WAS CONDUCTED AT:

NOTEWORTHY PRACTICES:

GRADE ASSIGNED:

REVIEWED BY:

$$
\text { Facility Manager }
$$


WESTINGHOUSE GOCO

CONDUCT OF CASUALTY DRILLS

DRILL SCENARIO
Manual

Attachment

Page

Effective Date
WHC-SP-1178

$D, \operatorname{Rev} 0$

14 of 18

February 15, 1996

\section{ATTACHMENT D}

\section{DRILL SCENARIO}

DRILL NUMBER:

PLANT IMPACT:

APPROVAL:

FACILITY MGR./DATE

TITLE:

I. INITIAL CONDITIONS

PLANT MODE:

SYSTEM/EQUIPMENT:

PARTICIPANTS :

SPECIAL EQUIPMENT:

PRE-DRILL NOTIFICATIONS:

SPECIAL CONDITIONS AND INSTRUCTIONS:

\section{PRECAUTIONS \& LIMITATIONS}

ABORT LIMITS:

OPERATIONAL LIMITS:

SAFETY LIMITS OR PRECAUTIONS:

DRILL TEAM DUTIES:

REFERENCES:

\section{DRILL INITIATION}

IV. EXPECTED RESPONSE

V. TERMINATION \& RESTORATION 


\section{ATTACHMENT E}

\section{DRILL SCENARIO}

DRILL NUMBER: DRAFT

PLANT IMPACT: MINOR

APPROVAL:

FACILITY MGR./DATE

TITLE: AIR SYSTEM LEAK FROM F-51

I. INITIAL CONDITIONS

PLANT MODE: Any

SYSTEM/EQUIPMENT: Compressed Air

PARTICIPANTS: $\quad$ Control Room, Service Systems

SPECIAL EQUIPMENT: None

PRE-DRILL NOTIFICATIONS: None

SPECIAL CONDITIONS AND

INSTRUCTIONS: $\quad T-25$ should be on line at the beginning of the drill with either T-194 or T-196 available.

\section{PRECAUTIONS \& LIMITATIONS}

ABORT LIMITS:

OPERATIONAL LIMITS:

SAFETY LIMITS OR
PRECAUTIONS: $17.3 / 4.2 .7$ Dump Heat Exchangers

DRILL TEAM DUTIES: The dri11 controller in the Control Room evaluates Control Room procedure and drawing use and control of the problem solving actions. Ensure appropriate actions are taken to maintain instrument air header pressure greater than 90 psig. The drill monitor in the field evaluates actions of the Service Systems Watch. Ensure That T-25 is not left to complete its post shut down purge with its outlet path isolated. (23-V27 must be left open until the filter is

unisolated or until the power to T-25 is turned off.)

REFERENCES: 
WESTINGHOUSE GOCO

CONDUCT OF CASUALTY DRILLS

EXAMPLE SCENARIO
Manua 1

Attachment

Page

Effective Date
WHC-SP-1178

$E, \operatorname{Rev} 0$

16 of 18

\section{ATTACHMENT E}

\section{DRILL INITIATION}

Crack open the F-51 drain valve $23-V-33$ to simulate a blown out cover gasket for the filter. Report to the Control Room that while walking past the air compressor area you heard abnormally loud air noise and you believe there is a leak.

\section{EXPECTED RESPONSE}

The Control Room should dispatch the Service Systems Watch to investigate the air leak. To isolate the air leak the Shutdown watch should first direct opening $23-\mathrm{V}-27$ to bypass the filter and then closing $23-\mathrm{V}-29$ and 23-V-30. In this way T-25 can remain on line until another tower can be placed in service.

\section{TERMINATION \& RESTORATION}

Secure from the drill when F-51 is isolated, T-25 is secured with another air dryer on line. Ensure that all valves operated are returned to their normal positions. 
WESTINGHOUSE GOCO

CONDUCT OF CASUALTY DRILLS

SUGGESTED DRILLS
Manual

Attachment

Page

Effective Date
WHC-SP-1178

$\mathrm{F}$, Rev 0

17 of 18

\section{ATTACHMENT $F$}

\section{LIST OF SUGGESTED CASUALTY DRILLS}

1. Loss of equipment power

2. Steam leak

3. Spill of radioactive liquid

4. Dry radioactive spill

5. Loss of cooling water

6. Loss of ventilation

7. Loss of breathing air

8. Loss of radioactive source

9. Small fire

10. Fire in electrical motor

11. Loss of communications

12. Alarm response drills

13. Spill of hazardous material

14. Loss of electrical power

15. Injured person

16. Missing watchstander

17. Lubricating oil leak

18. Loss of backup/emergency power 
WESTINGHOUSE GOCO

CONDUCT OF CASUALTY'DRILLS

REFERENCES
Manual

Attachment

Page

Effective Date
WHC-SP-1178

G, Rev 0

18 of 18

ATTACHMENT G

\section{REFERENCES AND RESOURCES}

DOE 5480.19, Conduct of Operations Requirements for DOE Facilities, of 5-18-92.

DOE 5480.20, Personnel Selection, Qualification, Training, and Staffing Requirements at DOE Reactor and Non-Reactor Nuclear Facilities, of 220-91.

DOE EM-25, Breakout Session on Conduct of Drills, Conduct of Operations Working Group.

WHC-SP-0329, Hanford 400 Area [Fast Flux Test Facility (FFTF)] Training Plan, July 1991. 
WHC-SP-1178

\section{DISTRIBUTION}

\section{ONSITE}

Central Files (2)

A3-88

O.S.T.I. (2)

G3-11

U.D.C. (5)

A3-95

Charles P. Ames

R2-40

Richard D. Raaz

R2-40 